\title{
Mediation as prevention of judicialization of health: narratives of judiciary and health subjects ${ }^{a}$
}

\author{
Mediação como prevenção à judicialização da saúde: narrativas dos sujeitos do judiciário e da saúde \\ Mediación como prevención de la judicialización de la salud: naratas de los sujetos del \\ judiciario y de la salud
}

Maria dos Remédios Mendes Oliveira ${ }^{1}$ Rackynelly Alves Sarmento Soares ${ }^{2}$ Maria Fátima de Sousa ${ }^{1}$ Ana Valéria Machado Mendonça ${ }^{1}$ Maria Célia Delduque ${ }^{1}$

1. Universidade de Brasília. Brasília, DF, Brasil.

2. Universidade Federal da Paraíba.

João Pessoa, PB, Brasil.
Corresponding author:

Maria dos Remédios Mendes Oliveira. E-mail: remediosmendes@hotmail.com

Submitted on $12 / 02 / 2018$.

Accepted on 03/30/2019.

DOI: 10.1590/2177-9465-EAN-2018-0363

\begin{abstract}
Objective: To analyze the phenomenon of judicialization for health mediation and prevention of judicial demands. Methods: Exploratory and explanatory mixed study, from 2017 to 2018, with a non-probabilistic sample. We used two structured interview scripts, one to the municipal health secretaries and another to the judges from the Public Treasury of the Brazilian territory. In common, the meaning of judicialization and mechanisms for resolution. For the 162 secretaries: reasons for the judicialization, alternatives for resolution and more demanded inputs; for the 40 judges, the legal basis. Results: $77.5 \%$ of the judges resorted to support in the legal actions; $77.5 \%$ of the districts do not count on mediation of sanitary conflicts; $65.4 \%$ of the municipalities have a group for mediation. The annual expense with the judicialization varies from less than $\mathrm{R} \$ 100$ thousand to more than one million. Conclusion: Despite the support for decisions and mediation groups, the judicialization of health centers enlarge courts and has an impact on the budget of municipalities and commit itself to the actions in primary health care.
\end{abstract}

Keywords: Health law; Health's judicialization; Health care; Public health.

\section{RESUMO}

Objetivo: Analisar o fenômeno da judicialização para a mediação sanitária e prevenção das demandas judiciais. Métodos: Estudo qualiquantitativo exploratório e explicativo, de 2017 a 2018, com amostra não probabilística. Utilizou-se dois roteiros de entrevistas estruturados, um para os secretários municipais de saúde e outro para os juízes de Varas de Fazenda Pública do território brasileiro. Em comum, o significado da judicialização e mecanismos de resolução. Para os 162 secretários: razões da judicialização, alternativas de resolução e insumos mais demandados; para os 40 juízes, o embasamento jurídico. Resultados: $77,5 \%$ dos juízes recorreram a apoio nas ações judicializadas; $77,5 \%$ das comarcas não contam com mediação de conflitos sanitários; $65,4 \%$ dos municípios contam com grupo para mediação. O gasto anual com a judicialização varia de menos de $R \$$ 100 mil a mais de um milhão. Conclusão: Apesar do apoio às decisões e grupos de mediação, a judicialização da saúde avoluma tribunais, impacta no orçamento dos municípios e compromete-se com as ações na atenção básica à saúde.

Palavras-chave: Direito sanitário; Judicialização da saúde; Atenção à saúde; Saúde pública.

\section{REsumen}

Objetivo: Analizar el fenómeno de la judicialización para la mediación sanitaria y prevención de las demandas judiciales. Métodos: Estudio cualitativo cuantitativo exploratorio y explicativo, de 2017 a 2018, con muestra no probabilística. Se utilizaron dos guiones de entrevistas estructuradas, uno para los secretarios municipales de salud y otro para los jueces de Varas de Hacienda Pública del territorio brasileño. En común, el significado de la judicialización y los mecanismos de resolución. Para los 162 secretarios: razones de la judicialización, alternativas de resolución e insumos más demandados; para los 40 jueces, el fundamento jurídico. Resultados: $77,5 \%$ de los jueces recurrieron a apoyo en las acciones judicializadas; $77,5 \%$ de las comarcas no cuentan con mediación de conflictos sanitarios; $65,4 \%$ de los municipios cuentan con un grupo para mediación. El gasto anual con la judicialización varía de menos de R $\$ 100$ mil a más de un millón. Conclusión: A pesar del apoyo a las decisiones y grupos de mediación, la judicialización de la salud acumula tribunales e impacta en el presupuesto de los municipios y comprometen sus acciones en la atención básica a la salud.

Palabras clave: Derecho sanitario; Judicialización de la salud; Atención a la salud; Salud pública. 


\section{INTRODUCTION}

Brazil began the $21^{\text {st }}$ century still in underdeveloped or a developing country. An underdevelopment that is characterized by socio-economic, political-cultural and environmental exclusion, by a lack of cohesion and social solidarity, by the insufficiency of economic and scientific-technological dynamism and, mainly, by the poverty and inequality as the biggest present day problems. Such situation places us among the countries with the greatest social inequality of the world. This inequality also extends on a regional, racial, of gender and rural basis and is present in the majority of the population at risk of the Northeastern and North: black, Indian, in the countryside and in the other metropolitan areas of deprivation and poverty. ${ }^{1}$

A real vilification of the fundamental rights and human dignity. The dignified life in the city does not only concern housing, it addresses the vital needs, and the right to health is not a determining factor in its planning. ${ }^{2}$ Even though the relevance of the theme, the practice and driving of the collective health in our municipalities are worrying, since the queues grow, increases the lack of Intensive Care Units - UTIs, the demands of specialized exams and consultations. It also includes the high-cost and not standardized medicines, and considerable demand for psychotropic substances and psychiatric hospitalizations due to the alcohol and other drugs abuse, leading to the recipe commitment aimed at the basic attention to comply with court orders.

The health, as a fundamental right is not realized through its inscription in article 6 of the 1988 Federal Constitution. ${ }^{3}$ It $s$ a social product to be constructed collective and individually, ensured for 30 years by article 196 of the $\mathrm{FC}^{3}$ and does not constitute yet access to goods and services in the scope of the Unified Health System (SUS). It requires permanent action of the State to ensure resources for financing of public health, to reduce the social and economic inequalities and contribute to regional development.

Country is facing one of the contemporary challenges of constructing a Unified Health System as a democratic State policy of law, guaranteed by the universal, equal, integral, decentralized and participatory to health services. At the same time as it should oppose the trend of a neoliberal society - state, in a counter-hegemonic movement. ${ }^{1}$ New groups and actors arise who demand their rights and for equality, expanding ever more the Right in the scope of the social relationships regulating new practices. Given the absence of State policies, there has been appealed to the judiciary, which has been starring in the effectiveness of the social rights, among them the right to health. ${ }^{4,5}$ In this context, this article deals with the search for the effectiveness of the Fundamental Right to Health in a municipal manager view as directly responsible for the health promotion and the judiciary, which establishes the compliance with the decisions on the basis of the legislation in force and jurisprudence of the Courts on the goods and services not standardized by SUS. Such decisions impact the organization of the municipalities budget, intervening in the public policy, due to the lack of competences definition within the SUS, breaking the isonomy and prevailing the individual right in detriment of the collective one. The health mediation is identified as an effective means for the establishment of the right to health.

\section{METHODS}

This is a qualitative and quantitative study. The quantitative design, exploratory and explanatory character used primary data collected through script of interview applied by electronic means. The study population invited to participate in the interviews through invitation letters was composed of Municipal Health Secretaries and Judges of Law from the Public Treasury of the Brazilian territory. For the respondents, we adopted a non-probabilistic sample of volunteers. This sample type is composed of subjects who volunteer to participate in the research in a non-random way. ${ }^{6,7}$ In this way, the results achieved from this type of sample may not be inferred from the universe. ${ }^{8,9}$

The data collection instrument included three scripts of structured interviews, available electronically and contained in a server at the University of Brasília (UnB) within a period of 21 months, from January 2017 to October 2018 . After the collection, the scripts were located off-line. These have addressed the specificities of the judicial system and the municipal and State health managers. We opted to analyze properly the specificities of the judicial system and the municipal managers.

The analytical categories applied to the judges were the meaning of the judicialization; the main legalistic demands and; alternatives to the disjudicialization. The profile of both participants was analyzed according to the variables: gender, age group and schooling.

The qualitative study applies to the techniques of content analysis ${ }^{7,8}$ used for understanding three of the ten questions submitted to the judges and that takes us back to the judicialization of health, to the foundation of theirs decisions and to the institutional framework of groups mediators of conflicts. For the municipal secretaries, of the 15 questions, five were analyzed in light of the judicialization of health and its reasons, the alternatives and mechanisms to avoid the judicialization and the most demanded health inputs are presented in five categories.

This research was approved by the Research Ethics Committee of the Faculty of Health Sciences at the University of Brasilia under number CAAE 32553014.3.1001.00.30.

\section{RESULTS}

\section{Profiles of the judges and municipal health secretaries}

After the deletion of the unfinished questionnaires, the universe under analysis counted on 40 respondents among the judges. Of the total, 15 (37.5\%) were female, while 25 (62.5\%) were male. Most of the subjects of the judiciary system were between 36 to 55 years old, which means 33 (82.5\%). In relation to the characterization, we still find $27(67.5 \%)$ with specialization and only nine $(22.5 \%)$ with doctorate degree. 
In relation to the question about the most used legal basis in the legal decisions the judges stated that they are based on Article 196 of the Federal Constitution (CF), 24 (71\%). Four (12\%) add to this the Law No. 8080/1990 in addition to the Federal Constitution and $5(15 \%)$ of respondents beyond these are based in the Jurisprudence by the Superior Courts.

With regard to the category, in particular, the meaning of the judicialization, the most, 20 (59\%) points out the judicialization of health because of poor management of the executive system and inability to manage the resources to meet adequately the demands for health needs. In this path 10 of the magistrates $(29 \%)$ responded, moreover, three $(9 \%)$ pointed out the poor management by a lack of knowledge of the SUS.

In the category on mechanisms to prevent the judicialization, only six $(18 \%)$ of the respondents said that there is a dispute board.

The universe under analysis for the municipal health secretaries counted on 162 respondents. A hundred of respondents $(61.7 \%)$ were female, while $62(38.3 \%)$ were male. The age group, in their majority, varied from 36 to 50 years old, which means 79 of the respondents (48.8\%). Still in relation to the characterization with regard to the qualification in the health area, $72(44.4 \%)$ are identified with specialization, eight (4.9\%) with doctorate degree and only two (1.2\%) with doctorate in the area.

With respect to the profession, the one that presented the highest frequency was that of nurses, with 39 (24.1\%), followed by seven pharmacists (4.3\%), while $87(53.7 \%)$ are dispersed in professions not belonging to the health sector. In the variable time as secretary of health, $86(56.1 \%)$ played the role of secretaries less than five years and $36(22.2 \%)$ played the role of secretaries of health for more than eight years. With respect to the monthly income, this varied between less than two minimum wages for six $(3.7 \%)$ and $16(9.9 \%)$ who received above ten minimum wages.

When asked about the yearly expenditure on the judicialization of health by the municipality, $83(51.2 \%)$ responded that their spending was up to $R \$ 100$ thousand, 23 (14.2\%) up to $R \$ 300$ thousand and nine (5.6\%) up to $\mathrm{R} \$ 1$ million. With respect to the existence of team or group set up for carrying out the mediation and sanitary conflicts, 54 (33.3\%) responded yes, 106 (65.4\%) answered no and two (1.2\%) responded that they did not know.

\section{What municipal judges and health managers say about the judicialization?}

Of the universe of the judges interviewed, 20 (59\%) responded that the judicialization takes place in accordance with the inefficiency of the management and claim that all demands that reach the judiciary could be resolved by the Executive Power.

In this way, 10 judges (29\%) say that the judicialization replaces the Executive Power when legal decisions determine the implementation of public policies by the slowness or indifference of the Executive Power.

The Figure 1 shows the opinion of the judges concerning the category what the judicialization means.
Figure 1. What the judicialization means for the judges. 2018. Source: OLIVEIRA, 2018.

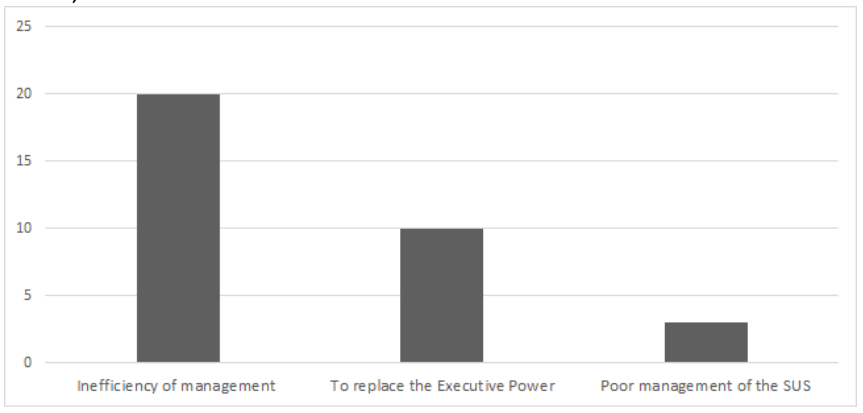

\section{The judicialization for the municipal health managers}

Forty-four (28\%) municipal health managers perceive the judicialization as a means of compliance with the law and of what is recommended by the SUS. Among the managers, $24(20 \%)$ perceive the judicialization as a risk to the SUS. Three (3\%) managers have admitted the lack of planning in the management (Figure 2).

Figure 2. The meaning of the judicialization for the municipal health managers. 2018. Source: OLIVEIRA, 2018.

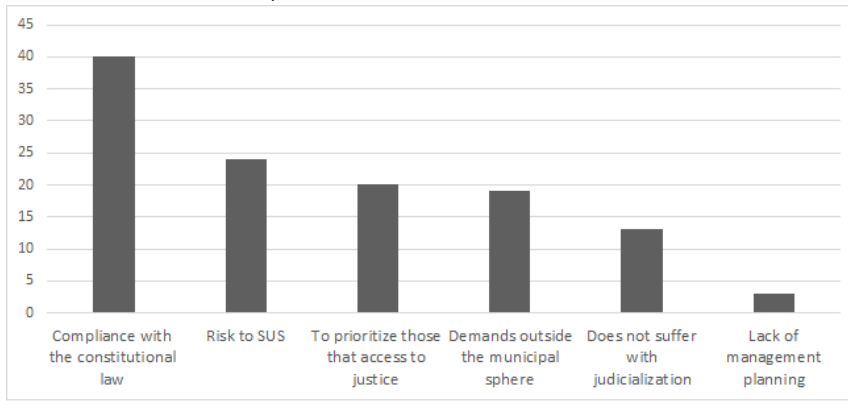

\section{Resolution mechanism of the judiciary and of the municipal health managers}

Of the respondents of the Judiciary, only six (18\%) responded that there is in their districts resolution mechanisms of the health conflicts.

Of the universe of 162 municipal health managers only eight $(5 \%)$ have said there is sanitary mediation, however, were not able to respond about the institutionality, only one mentioned that there was a partnership with the Court of Justice - TJ.

\section{The legal foundations that underlie the legal decisions}

The article 196 of the CF is the most cited in the judicial decisions guarantors of the claimed right $24(71 \%)$, in addition to Jurisprudences of the Superior Courts, (15\%), and the Law No. 8080/1990 (12\%). 


\section{Reasons for the judicialization in the municipal health manager's view}

In Figure 3, it can be seen that, in the managers respondents' view, $44(28 \%)$ stated that these demands are to enforce the law concretizing the right to health that the management ceases to meet. Of the managers, $41(26 \%)$ argue that respond for demands of competence of other Federative entity.

Figure 3. Reasons for the judicialization for municipal health secretaries. 2018. Source: OLIVEIRA, 2018.

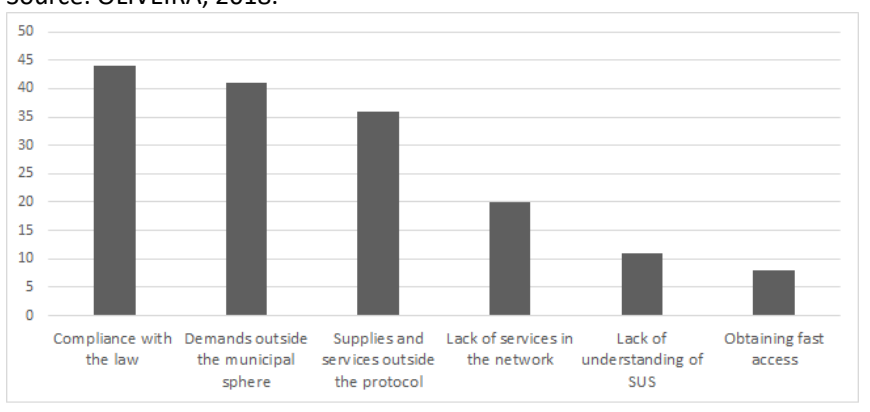

Another reason for the judicialization, according to the managers, are the prescribers, which, when coming from the SUS network, do not observe what already exists standardized.

When the prescribers do not have any link with the SUS, they prescribe medicines, goods and services not contemplated by the System, answered by $36(23 \%)$. In addition to these reasons, eight $(5 \%)$ emphasized that this is a way of prioritizing those that have access to the justice. The judicialization of health is the last resource to provide access to healthcare, accessible for low-income citizens through the Public Defender. ${ }^{10}$ Twenty $(12 \%)$ claim that it is due the lack of the network services in the municipality.

\section{Management alternatives to avoid the judicialization}

In the face of the disturbance due to the budget commitment, the municipal managers seek alternatives to avoid the judicialization in a way to guarantee and enlarge the health services. This is what do the 25 (15\%) managers who seek the Institutions to subsidize with information about how function the SUS, eight $(5 \%)$ in multidisciplinary team seek to replace the income for those provided in the network, nine $(6 \%)$ count on Mediation cameras, and $102(63 \%)$ have not found or sought alternatives for the judicialization.

\section{Main demands of the judicialization}

The medicine is still the greater legal demand, 117 (55\%). The other demands indicated by the secretaries are food diet 25 (12\%); surgery $18(9 \%)$; exams $16(8 \%)$; diapers $11(5 \%)$; hospital bed eight (4\%) and surgical materials eight (4\%).

\section{DISCUSSION}

The Federal Constitution of 1988 recognizes the right to health as a fundamental right, being relevant to state that the norms that guarantee it have immediate application, in the form pursuant to $\S 1^{\text {st }}$ of the $5^{\text {th }}$ article of the constitutional text. Established constitutionally, the health becomes a legal good covered by the State. Thus, declared the right, this is established, either by means of laws or by means of effective public policies. Moreover, in their absence and of the non-compliance of goods and health services offering, the citizen turns to the judiciary to guarantee and implement its right.9,11 The judicialization of health requires immediate responses from the judiciary management, particularly in cases in which the claimant is at risk of life, limiting the time for decision and judgement. The decisions are based on the principle of the dignity of the human person for assuring the citizen of the effectivity of the right to health..$^{5,12}$

With regards to the category, the meaning of the judicialization, the majority, 20 (59\%), point out the judicialization of health as a consequence of poor executive power management and inability to manage resources for meeting adequately the health demands, arriving at provoking due to its inoperativeness, its replacement by the judiciary when from its decisions it is required to create public policies.

The lack of knowledge on the part of the public management could be an indicator of the system poor management and could explain why the citizen does not find essential medicines available in local pharmacies. The number of judicial demands with prescription of new technologies has also grown. It is important to emphasize that Brazil is one of the pharmaceutical markets with the highest growth rate in the world.

There is a huge gap between the exercise of the right to health and the means not made available by the public management.

The judicialization occurs throughout the country causing trouble in the judiciary that already in itself is no longer sufficient to meet and solve the extensive demand with the speed and efficiency necessary for the health demands. The non-judicial alternative dispute resolution have not gained forces even with the advent of the Law 13.140 that deals with the mediation. ${ }^{9}$ By providing the exercise of citizenship associated with the practice of the sanitary mediation, alternative dispute resolution method in the health sector adopted in the municipal secretaries, possibly, there will be a considerable reduction of disputes and judicial demands. ${ }^{13,14}$

Of the universe of the judges interviewed, 20 (59\%) responded that the judicialization is due to the management inefficiency and claimed that the demands that reach the judiciary could be resolved by the Executive Power, which, in turn, neglect the citizen attention, even the one already provided by means of the Public Policies. The management failures 
noted by the respondents, concern, mainly the centralization of medicines dispensation to patients with diseases that require continuous treatment.

What the judicialization means, and reaffirms the speech of the Judge 1 who says: "there is no attention in the health units, which determines the interposition of actions to obtain what the legislation already provides or to make it achievable". As to the Judge 2, the judicialization "brings to the scope of the Judiciary responsibility what should be implemented by the Executive".

Although the health is a constitutional right, its implementation is not yet a reality, requiring management efficiency, which corresponds to reality, let us see: the public policy of medicines was due to the great legal demand in the 1990s, this is a twentyyear agenda. In this respect, 10 judges $(29 \%)$ say that the judicialization replaces the Executive when legal decisions determine the implementation of public policies by the tardiness or indifference of the Executive, as responds the Judge 3: "the judicialization replaces the Executive that does not take care efficiently of the health", and others add that "is the last resource to achieve the access to the Right to Health when the State shall ensure it." In the lack of health services, the citizen would not have any choice as to appeal to the Judiciary Branch to guarantee the constitutional right protection. ${ }^{15}$ The Legislative and Executive powers are responsible for the implementation of the right to health. When the state spheres fail to implement the right to health in the ways proposed by the Constitution, they shift to judiciary the role of ensuring the exercise to the implementation and realization of the fundamental rights constitutionally accepted. ${ }^{5}$ The fundamental right to health must be interpreted, extensively, in a way to ensure democratically the wide protection of human beings. The fundamental rights must not be restricted, and the interpreter should apply them as comprehensively as possible. ${ }^{5}$

For municipal health managers $44(28 \%)$ the judicialization is regarded as a means of compliance with the law and of what is recommended by the SUS, corroborating previous studies, which point out the lack of understanding of the System by the municipal managers. ${ }^{5,16,17}$

For Manager 1 "it means loss throughout the programming planned for the basic attention". For Manager 2, however, such question "is usurpation of resources that the management would use to make investments". It becomes hard for the public management when the decisions commit the purchase of more expensive medicines without confirmation of its efficacy and safety, as reaffirmed in previous studies. ${ }^{18}$ The manager 3 says there is a "significant decrease in the implementation of public policies, favoring a citizen, disfavoring the collective". Studies point out that the legal decisions favorable to individual pleading can compromise resources that are enough for the entire population. ${ }^{19}$ Even by realizing, the budget planning to implement the public health policy this can be impaired by legal decisions that can ensure the right of one, obliging the management to stop improving such questions in the basic attention programs. ${ }^{13,17,20}$ Among the managers, 24 (20\%) see the judicialization as a risk for the SUS conceptions, since the principle of equality is not observed, the waves regulatory mechanism is amended, making planning impossible, leaving without control the budget and financial forecasting, as shown in the speech of Manager 4: "The deviation from a financial flow that could help thousands of people, prevention projects support is intended to comply with legal measures. In addition to interfering in the public management planning, the legal decisions impact on guarantee of the right to health of the collectivity. Three $(3 \%)$ managers admitted the lack of planning in the management. We must emphasize that the amendments in their great majority are sponsored by the Public Defender, which by the scope of obtaining a favorable decision compels the executive to put into practice the right. The Public Defender stands out as the voice of the neediest persons and the Judiciary as the one that assist the minorities. ${ }^{21}$

In agreement with reports of the Judiciary, the municipal management reinforces the need for an institutional dialogue. The experience of the institutional dialogue is already an experience in some municipalities and districts, and point out positive results from the implementation of the right to health in a quick way and from the construction of the SUS functioning. Furthermore, they show the importance of the everyday space as a mobilizing agent of informal and, simultaneously, specific strategies of the health realization, pointing out the sanitary mediation as an effective means in the resolution of the health sector conflicts.

Of the respondents of the Judiciary, only six $(18 \%)$ responded that there is in their districts mechanisms for resolution of sanitary conflicts. These cited Chambers and Nuclei, and only one of them said to look for a solution before the judicialization. The organs of the Judiciary have made efforts to reduce the judicialization of health. The resolution of sanitary conflicts by the Sanitary Mediation brings the possibility of being step ahead of the future conflicts. ${ }^{14}$

Other organs have implemented a mechanism for resolution with the aim to reduce the number of demands involving the theme, by using, in particular, some institutionalized form of mediation. ${ }^{22}$ However, even if these initiatives have reached satisfactory solution to the sanitary conflicts, the mediation remains outside the place where the conflicts take place. It is in the Health system where their conflicts must be solved..$^{14}$

Of the universe of 162 municipal health managers only eight of these (5\%) said there is sanitary mediation, however they were not able to respond about the institutionality, only one mentioned that there was a partnership with the Court of Justice - TJ.

Indeed, studies indicate alternative ways for resolution of sanitary conflicts-Judiciary related, after formalizing the process. This negotiation does not concern the health management, which could lead to high expenses to meet the demand, since this entails costs may result in extraordinary amounts with administrative processes of bid proceedings. Such situations 
end up competing with the normal supplies of the SUS, leading an irregular division of material, human and budgetary efforts to meet the judicialization. The same applies in the Judiciary Power. The new influx of processes in the area of social rights, among them, those of health, made the judicialization has a larger input in the already overburdened judicial system. ${ }^{5}$

Highlighting that the Health is a Fundamental Right the STF has held the position that there is no interference by powers when established by the judicial decisions on social right inserted in the FC as Constitutional Right. Equally, the Right to Health is established in the Constitution and explained by the infra-constitutional laws. As such, it is essential that the Judiciary should established it even if it has an effect on the budget of the Executive. ${ }^{16}$ In order to take account of the inclusion and integral protection to the human person, the right to health, corollary of this principle, has been oriented the judiciary in its decisions and judgements. The right to health is showing, in this sense, as a relevant means within the individual's reach to the own right to life. The Law $8080 / 1990$ has monitored the basement and decisions by the superior Courts, which, in turn, have confirmed the constitutional right to health as principle and rule, based on the premise of the establishing of the dignity of the human person into the democratic state under the rule of law.

In the Managers respondents' view, 44 (28\%) stated that the demands occur to enforce the law fulfilling the right to health that the management ceases to meet. Of the managers, $41(26 \%)$ replied that respond for demands of competence of another Federative entity. Thus, the Manager 5 reported: "disinformation about competence of the federated entities in financing the SUS complexity and solicitation of nonstandardized drug products without exhausting the RENAME and REMUME" alternatives. The National List of Essential Drug Products - RENAME establishes the dispensing and products by the SUS federal manager, such list, also defines at the national level the drugs, products and the procedures that should be delivered to the SUS population. The drugs are divided in groups with the purpose of uncomplicating the public actuation of their dispensing. ${ }^{23}$ Due to regional differences, these lists are not definitive given the financial autonomy of the state and municipal management. These entities, according to the epidemiological profile can adopt complementary relations of drugs, products and procedures agreed with the Councils of Municipal Health and the Bipartite Inter-Commissions- CIB, considering the Municipal Lists of Essential Drugs- REMUME and observing the last list of essential drugs of the World Health Organization - WHO, of the RENAME. In addition to the protocols of the Ministry of Health - MS. As it shows, the SUS is a complex system that must be understood by the public managers to reach the concreteness of the right to health, thus preventing that, by default, another system, the Judiciary enforce the legal compliance and determine the creation of public policies. The respondents indicate that the judicialization is also due to medicines that are on the RENAME and the REMUME by a lack of access to health services and it is a high-cost medication not incorporated into the system. It is necessary to know the System to enhance its functioning to allow it to successfully play its role, for this purpose, some managers are proposing subsidizing the subjects of the Justice System with information of the Health System appointed to establish partnerships in order to reach extrajudicial solutions. The sanitary mediation is an important strategy in which the solution is found by the own system which is recognized, adjusted and strengthened when the right to health is achieved. ${ }^{14,15,17,20,24}$

Another reason for the judicialization, according to the managers, are the prescribers, which, when coming from the SUS network, do not observe what already exists standardized. For Manager 6 "the main reasons of the judicialization is the failure of the medical team to prescribe items of the RENAME AND REMUME".

The findings of this study meet other similar studies, with regard to the medical prescription as the main foundation for the judicial decision ${ }^{20}$ since these prescriptions are signed by supplementary or autonomous prescribers of the health network.

In the face of the Executive Power difficulty in fulfilling its institutional duty, the citizen has found a new way of access through judicial proceedings. This phenomenon known as "judicialization of health" includes the provocation and the actions of the Judiciary Power towards the realization of the medical and/or pharmaceutical assistance. The Executive, in turn, becomes constrained, in the courts, providing, in a nondiscriminatory way, medical and pharmaceutical assistance, provoking repercussions both on the health policy and on the public coffers.

An efficient way of solving conflicts and the access to justice is the Mediation. This way of solving conflicts, already used in Brazil presents itself as a potent instrument for the resolution of conflicts of several natures and scholars have been indicated it for the resolution of conflict of the health sector in the context of the SUS. The sanitary mediation as an instrument for resolution, gives rapid response to the citizen who seeks realization of its right to health. Through the dialogue the parts know the reasons, the limits and aim of finding the solution for their demands in the own System. Once the SUS adopt the sanitary mediation, it opens up the possibility for foreseeing and anticipating, by assuaging the effects on a continued attention to the conflicts. ${ }^{13,14}$

The construction of Sanitary Mediation nuclei, in the context of the Health Secretaries at all levels, to use the Mediation internal to the system and external with their users, it must be a new paradigm to replace the litigation and the judicialization. ${ }^{14}$

Even though the policy of medicines has been deployed for more than two decades, the drug still holds the greatest legal demand, with 117 respondents (55\%). This demand draws since 1990s, with demands for antiretroviral drugs for HIV/AIDS, and since then it has an important role as an alternative way by the citizen on access to medicines in the Brazilian Health Single System (SUS). ${ }^{24}$ 
The access to medicines is an important public policy. Brazil has one of the most advanced programs of the world in the treatment of the HIV/AIDS; however, paradoxically there are no essential drugs continuously in the local pharmacies. ${ }^{12}$ The further demands indicated by the secretaries are food diet 25 (12\%); surgery $18(9 \%)$; exams $16(8 \%)$; diapers $11(5 \%)$; hospital bed eight $(4 \%)$ and surgical materials eight $(4 \%)$. With respect to the food diet, add special milks and enteral diet to this. The high demand of legal actions in health is a challenge that we will face before the threat to the universal public health system and call us to a reflection that imposes us to be alert to the interests of the private insurances with offers of available plans that lead us to forget the Public Power deficiencies. ${ }^{17}$

\section{CONCLUSIONS AND IMPLICATIONS FOR PRACTICE}

Among the conclusions of the study is the need for a better understanding of the Health System by the Magistrates that repress the Executive to comply with what determines the FC in accordance with the Law 8080/1990 and Complementary in order to contribute with the sustainability of the System, without prejudice to the right of the citizen. Likewise, the Managers must direct beyond the knowledge of the Health System, anticipating to the population demands in which refers to the Basic Health Care, to comply with its competence without accounting unnecessarily for the attributions of other Federative Entity.

It is observed that $87(53.7 \%)$ of managers do not have training in the health area and $86(53.1 \%)$ have been in management for less than four years, that is, this is non-training in the area and the turnover in the management without complying with the technical training, which could lead to the system malfunction. Let us also note the fact that, being the most part of respondents of the municipal managers composed of nurses, it means that the category is always present in the processes of organization of the Brazilian Health Single System. Therefore, the one responds, directly, for the care to the prevention of legal processes, since it remains in the front line to respond the main questions along with the users of the network.

In addition to what is noticeable by the managers' speeches the importance of the SUS functional knowledge by the Institutions so that, when demanded, can respond to the competent entity.

It is relevant to highlight the sanitary mediation as an effective alternative to the Judicialization, in which 102 (63\%) of managers, when indicating the dialogue, move towards the possibility of sitting at the table with the citizen and solving the problem before it reaches the judiciary.

\section{REFERENCES}

1. Sousa MF. Programa de saúde da família: estratégia de superação das desigualdades na saúde? análise do acesso aos serviços aos serviços básicos de saúde. [tese]. Brasília: Universidade de Brasília; 2007. Available from: http://repositorio.unb.br/bitstream/10482/3014/1/2007_ MariaFatimadeSousa.PDF
2. Oliveira TMV. Amostragem não Probabilística: Adequação de Situações para Uso e Limitações de Amostras por Conveniência, Julgamento e Quotas. Adm On Line [Internet]. 2001; Jul/Aug/Sep; [cited 2018 Mar 6]; 2(3). Available from: https://gvpesquisa.fgv.br/sites/gvpesquisa. fgv.br/files/arquivos/veludo_-_amostragem_nao_probabilistica_ adequacao_de_situacoes_para_uso_e_limitacoes_de_amostras_por_ conveniencia.pdf

3. Senado Federal. (BR). Secretaria de Editoração e Publicações. Coordenação de Edições Técnicas. Constituição da República Federativa do Brasil. Texto constitucional promulgado em 5 de outubro de 1988, com as alterações determinadas pelas Emendas Constitucionais de Revisão nos 1 a 6/94, pelas Emendas Constitucionais nos 1/92 a 91/2016 e pelo Decreto Legislativo no 186/2008. Brasília (DF): Senado Federal 1988. Available from: https://www2.senado.leg.br/bdsf/bitstream/handle/ id/518231/CF88_Livro_EC91_2016.pdf

4. Campos Neto OH, Gonçalves LAO, Andrade EIG. A judicialização da Saúde na percepção de médicos prescritores. Interface (Botucatu) [Internet]. 2018;22(64):165-76. Available from: http://www.scielo.br/scielo. php?pid=S1414-32832017005009103\&script=sci_abstract\&tlng=pt

5. Costa FV, Motta ID, Araújo DA. Judicialização da saúde: a dignidade da pessoa humana e a atuação do Supremo Tribunal Federal no caso dos medicamentos de alto custo. Rev Bras Polít Públicas (Brasília) [Internet] 2017;7(3):844-74. Available from: https://www.publicacoesacademicas. uniceub.br/RBPP/article/view/4809

6. Lakatos EM, Marconi MM. Metodologia do trabalho científico: procedimentos básicos, pesquisa bibliográfica, projeto e relatório, publicações e trabalhos científicos. 7a ed. São Paulo: Atlas; 2013.

7. Bardin L. Análise de Conteúdo. São Paulo: Edições 70; 2009.

8. Minayo MCS. O Desafio do Conhecimento: pesquisa qualitativa em saúde. 14a ed. São Paulo: Hucitec; 2014.

9. Sarlet IW. Algumas considerações em torno do conteúdo, eficácia e efetividade do direito à saúde na Constituição de 1988. Interesse Público. 2001;3(12):91-107.

10. Oliveira MRM, Delduque MC, Sousa MF, Mendonça AVM. Judicialização da saúde: para onde caminham as produções científicas? Saúde Debate (Rio de Janeiro) [Internet].2015 Apr/Jun;39(105):525-35. Available from: https://www.revistas.usp.br/rdisan/article/view/13117/14920

11. Aith F, Bujdoso $Y$, Nascimento PR, Dallari SG. Os princípios da universalidade e integralidade do SUS sob a perspectiva da política de doenças raras e da incorporação tecnológica. Rev Dir Sanit (São Paulo) [Internet]. 2014;15(1):10-39. Available from: https://doi.org/10.11606/ issn.2316-9044.v15i1p10-39

12. Bielhl J, Petryna A. Tratamentos jurídicos: os mercados terapêuticos e a judicialização do direito à saúde. Hist Ciênc Saúde Manguinhos [Internet].2016;23(1):173-92. Available from: http://www.scielo.br/scielo. php?pid=S0104-59702016000100173\&script=sci_abstract\&tlng=pt

13. Oliveira MRM, Delduque MC, Sousa MF, Mendonça AVM. Mediação: um meio de desjudicializar a saúde. Temp Actas Saúde Coletiva (Brasília) [Internet]. 2016 Mar;10(1):169-77. Available from: http://www. tempusactas.unb.br/index.php/tempus/article/view/1860

14. Delduque MC, Castro EV. A Mediação Sanitária como alternativa viável à judicialização das políticas de saúde no Brasil. Saúde Debate [Internet]. 2015;39(105):506-13. Available from: http://www.scielo.br/scielo. php?pid=S0103-11042015000200506\&script=sci_abstract\&tlng=pt

15. Araújo DV, Distrutti MSC, Elias FTS. Priorização de tecnologias em saúde: o caso brasileiro. J Bras Econ Saúde [Internet]. 2017;9(Suppl 1):4-40. Available from: http://docs.bvsalud.org/biblioref/2017/09/859393/jbes9suppl1-02-nota-tecnica.pdf

16. Marques SB. Judicialização do Direito à Saúde. Rev Dir Sanit (São Paulo) [Internet]. 2008. Jul/Oct;9(2):65-72. Available from: https://www. revistas.usp.br/rdisan/article/view/13117/14920

17. Paula CEA, Bittar CML. Judicialização da saúde e seus reflexos na gestão do sistema único de saúde (SUS). Rev Dir Hum Efet (Brasília) [Internet].2017 Jan/Jun;3(1):19-41. Available from: https://indexlaw.org/ index.php/revistadhe/article/view/1866/pdf

18. Neto AJF. Judicialização da Saúde. Cad Mídia Saúde Pública. Volume II. Belo Horizonte; 2007. 
19. Paradela VAS. Judicialização da saúde. Rev Procuradoria Geral do Município de Juiz de Fora. 2011;1(1):153-66.

20. Mazza FF. Direito à Saúde, Poder Judiciário e Orçamento Público. Cad Ibero-Amer Dir Sanit (Brasília) [Internet]. 2014 Jul/Sep;3(2):54-61. Available from: https://www.cadernos.prodisa.fiocruz.br/index.php/ cadernos/article/view/9

21. Machado MAA, Acurcio FA, Brandão CMR, Faleiros DR, Guerra Jr $A A$, Cherchiglia ML, et al. Judicialização do acesso a medicamentos no Estado de Minas Gerais, Brasil. Rev Saúde Pública [Internet]. 2011 Apr;45(3):590-8. Available from: http://www.scielo.br/scielo. php?script=sci_arttext\&pid=S0034-89102011000300018
22. Ribeiro WC. A mediação como meio de resolução de conflitos na área de saúde. Rev Dir Sanit (São Paulo) [Internet]. 2018 Nov/Feb; 18(3):62-76. Available from: http://www.revistas.usp.br/rdisan/article/ view/144648

23. Mendonça SMF. Medicamentos de alto custo: a judicialização e o papel do Estado. [Monografia]. Centro Universitário de Brasília - UniCEUB. Available from: http://repositorio.uniceub.br/retrieve/22717/21171143. pdf.

24. Duarte CS, Braga PVB. A utilização dos protocolos clínicos e diretrizes terapêuticas e a racionalização da judicialização do direito à saúde. Rev Dir Sanit (São Paulo) [Internet]. 2017 Mar/Jun;18(1):171-90. Available from: http://www.revistas.usp.br/rdisan/article/view/135348

\footnotetext{
a Article derived from doctoral thesis defended in February 2019 along with the Post-Graduation Program in Collective Health, by the University of Brasilia under the guidance of the Prof. Dr. Maria Célia Delduque Nogueira Pires de Sá, with the title: Sanitary mediation as a prevention of the judicialization of health study of multiple cases in the Brazilian municipalities.
} 